Click www.researchjournal.co.in/online/subdetail.html to purchase.

\title{
Evaluation of impact of chemical treatment on clogged drip irrigation system
}

S.P. Nikam and P.G. Pophale

See end of the Paper for authors' affiliation

Correspondence to :

\section{S.P. Nikam}

Department of Agricultural

Engineering, College of

Agriculture, Dhule

(M.S.) India

Email:spnikma74@

gmail.com
-ABSTRACT : The experiment was conducted on farmer's field at Vivare, Tal-Raver, dist-Jalgaon to study the impact of chemical treatments on clogged drip irrigation system. Total 27 laterals of $12 \mathrm{~mm}$ diameter having length 25 meters each, on which 20 clogged emitters of 41 ph discharge were mounted at a spacing of $1.25 \mathrm{~m}$. The discharge of 10 emitters from each lateral was measured at a pressure of $1 \mathrm{~kg} / \mathrm{cm}^{2}$ for 5 minutes before treatment. The three types of acid that is hydrochloric acid (35\% conc.), sulphuric acid (98\% conc.) and nitric acid (60\% conc.) were used for acid treatment. The acid treatment was given at different $\mathrm{pH}$ levels viz., 3, 3.5 and $4 \mathrm{pH}$.It was found that when the $\mathrm{pH}$ of water was greater than 7.0, precipitation of salts occurred in the drippers. The water having electrical conductivity $1.45 \mathrm{mmhos} / \mathrm{cm}$ when passed through the drip system, most of emitters were clogged. The uniformity co-efficient of drip system before and after acid treatment was 84.03 per cent and 96.20 per cent, respectively. The average percentage reductions in discharge of clogged emitters were observed in between 42.5 per cent to 45 per cent. The average percentage increased in discharge was observed 68.18 per cent when clogged emitter was treated with $\mathrm{HC} 1$ (35\% cone.) having $3 \mathrm{pH}$ cone. The best chemical treatment of hydrochloric acid (35\% cone.) having $3 \mathrm{pH}$ was more effective to water having electrical conductivity $1.45 \mathrm{mmhos} / \mathrm{cm}$ for obtaining maximum discharge.

- KEY WORDS : Drip irrigation, Clogging, Chemical treatment, Uniformity co-efficient

— HOW TO CITE THIS PAPER : Nikam, S.P. and Pophale, P.G. (2019). Evaluation of impact of chemical treatment on clogged drip irrigation system. Internat. J. Agric. Engg., 12(1) : 107-111, DOI: 10.15740/HAS/IJAE/12.1/107-111. Copyright@2019: Hind Agri-Horticultural Society. 